Prepared for the National Aeronautics and Space Administration

\title{
Geologic Map of MTM -15027, -20027, -25027, and -25032 Quadrangles, Margaritifer Terra Region of Mars
}

By Rossman P. Irwin, III, and John A. Grant

Pamphlet to accompany

Scientific Investigations Map 3209

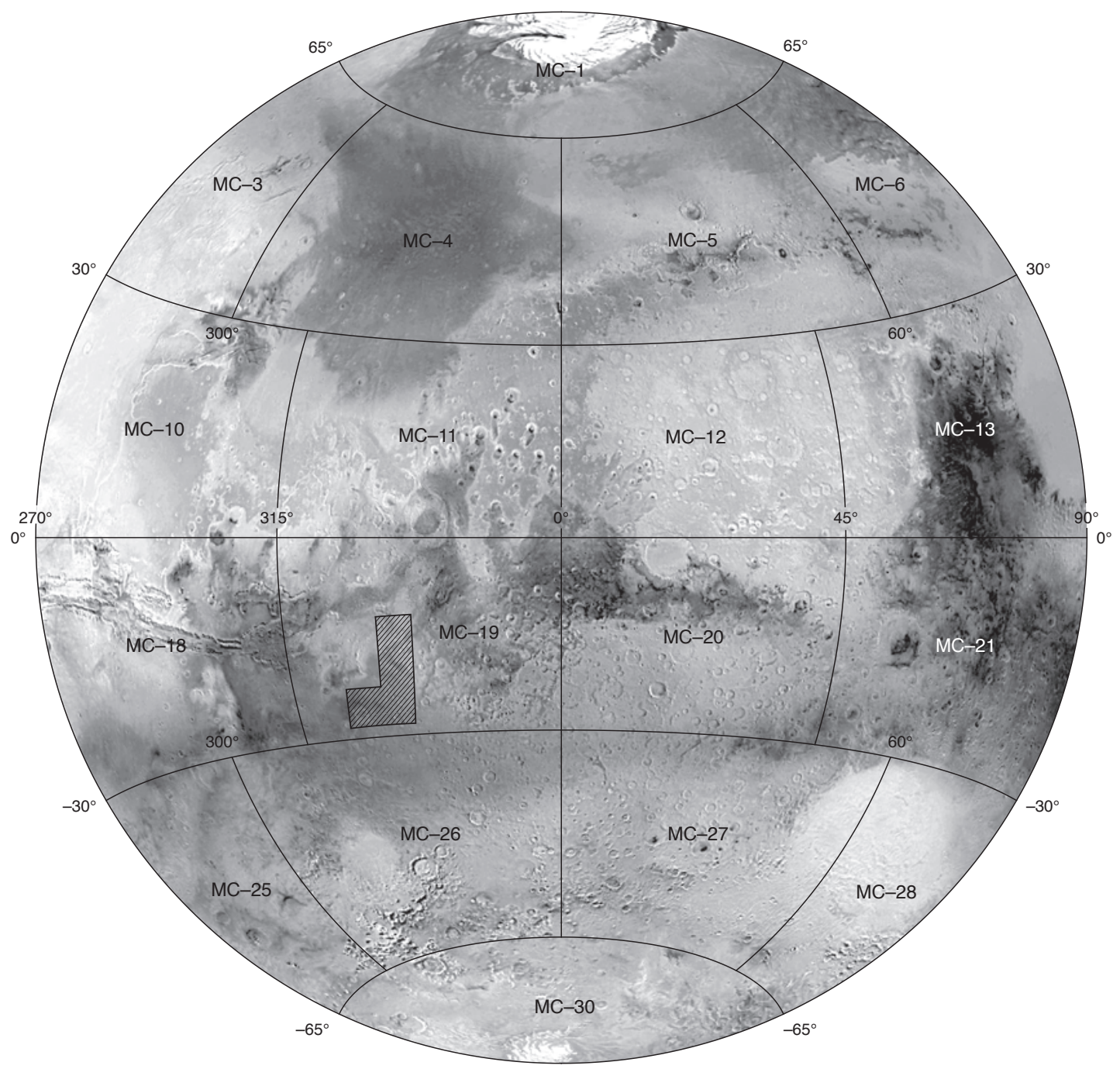

U.S. Department of the Interior

U.S. Geological Survey 


\section{Contents}

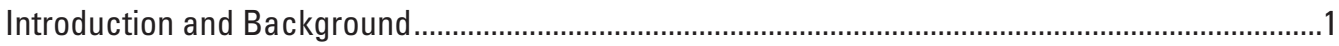

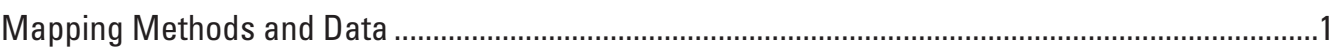

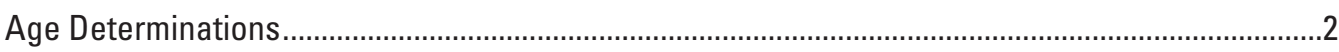

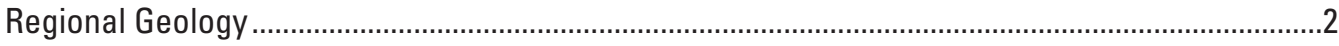

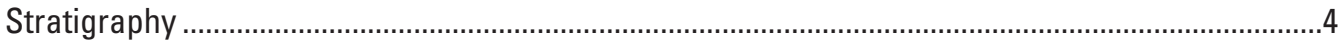

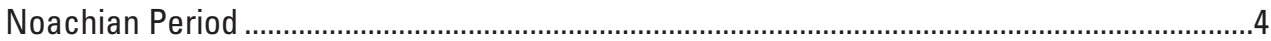

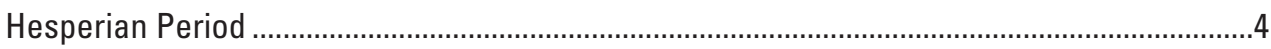

Amazonian Period .................................................................................................................

Structural Features

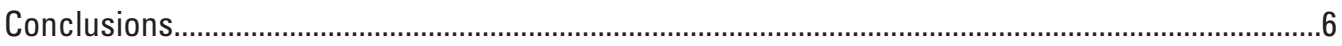

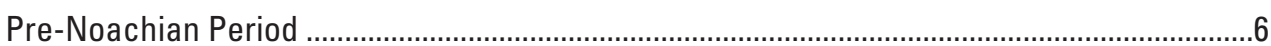

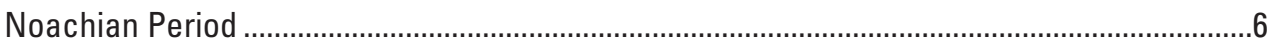

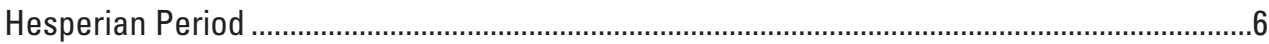

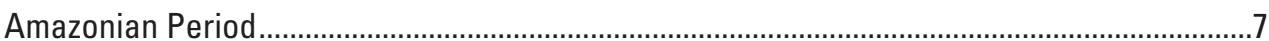

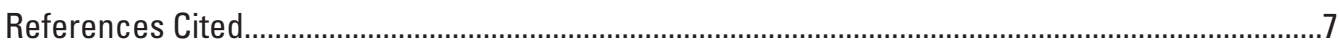

\section{Table}

1. Crater counts for spatially extensive map units. …………...............................................10 


\section{Introduction and Background}

Mars Transverse Mercator (MTM) quadrangles -15027 , $-20027,-25027$, and -25032 (lat $12.5^{\circ}-28^{\circ} \mathrm{S}$., long $330^{\circ}-335^{\circ}$ E. and lat $22.5^{\circ}-28^{\circ} \mathrm{S}$., long $324.5^{\circ}-330^{\circ}$ E.; figs. 1,2 ) in southwestern Margaritifer Terra include diverse erosional landforms, sedimentary deposits, and tectonic structures that record a long geologic and geomorphic history. The northeastern regional slope of the pre-Noachian crustal dichotomy (as expressed along the Chryse trough) and structures of the informally named Middle Noachian or older Holden and Ladon impact basins dominate the topography of the map area (Schultz and Glicken, 1979; Schultz and others, 1982). A series of mesoscale outflow channels, Uzboi, Ladon, and Morava Valles, integrated these formerly enclosed basins by overflow and incision around the Noachian/Hesperian transition, although some flooding may have occurred earlier (for example, Florenski and others, 1975; Pieri, 1980; Boothroyd, 1982; Parker, 1985, 1994; Grant, 1987, 2000; Grant and Parker, 2002). The area includes excellent examples of Late Noachian to Hesperian valley networks (Baker, 1982; Carr, 1996), dissected crater rims, alluvial fans, deltas, and light-toned layered deposits (LTLDs), particularly in Holden and Eberswalde craters (for example, Malin and Edgett, 2000, 2003; Grant and Parker, 2002; Moore and Howard, 2005; Pondrelli and others, 2005, 2008; Lewis and Aharonson, 2006; Grant and others, 2008). Structural forms include Tharsis-radial grabens, Hesperian wrinkle ridges, floor-fractured impact craters, and severely disrupted chaotic terrains (for example, Grant, 1987; Chapman and Tanaka, 2002). These well-preserved landforms and sedimentary deposits represent multiple erosional epochs and discrete flooding events, which provide significant insight into the geomorphic processes and climate change on early Mars.

Previous mapping of the area at smaller map scales includes the 1:5,000,000 map by Saunders (1979) and the 1:15,000,000 map by Scott and Tanaka (1986), based on Mariner 9 and Viking Orbiter data, respectively. Saunders (1979) observed that Holden crater was unusually deeply eroded for a stratigraphically young crater with relict secondaries, and he interpreted the interior fill as fluvial deposits modified by wind. His 1:5,000,000 map also noted mountainous materials that were remnants of impact structures and smooth plains of aeolian or volcanic material in the Ladon impact basin. Both this and the later 1:15,000,000 map recognized the area's major channels and chaotic terrains. Scott and Tanaka (1986) subdivided the highland surface into hilly, cratered, and subdued cratered units, and they mapped Holden as a superimposed impact crater with aeolian or volcanic fill. Parker and Pieri (1985a,b) completed a geologic/geomorphic map of the region and identified many of the basic units and structures identified here, although they lacked the resolution to subdivide basinfloor deposits. Grant (1987) mapped drainage divides, valleys, impact craters, and faults in the Margaritifer Sinus quadrangle to constrain its geomorphic history. He described the influence of degraded craters and other topographic features on the development of fluvial landforms. Pondrelli and others (2005, 2008) mapped and interpreted stratigraphic units in Holden and Eberswalde craters. In Holden crater, Pondrelli and others (2005) identified deposits equivalent to the layered, Holden central, and fan 2 units described below, but their interpretations differ from ours in several respects. They interpreted the western alluvial bajada as mass-wasting materials, did not identify the crater's central ring structure, and interpreted bouldery deposits and eroded terrain emerging from Uzboi Vallis as having a glacial rather than flood origin. Pondrelli and others (2008) interpreted three depositional sequences in Eberswalde crater that could not be defined at the scale of our map, and Rice and others $(2011,2013)$ mapped small outcrops and structures in Eberswalde. Other recent papers focused on the map area's major sedimentary deposits, which are discussed below (Malin and Edgett, 2000, 2003; Grant and Parker, 2002; Moore and others, 2003; Jerolmack and others, 2004; Bhattacharya and others, 2005; Moore and Howard, 2005; Pondrelli and others, 2005, 2008; Lewis and Aharonson, 2006; Wood, 2006; Grant and others, 2008; Milliken and Bish, 2010). These four quadrangles are part of a series of 1:500,000- to 1:1,000,000-scale maps in Margaritifer Terra sponsored by the National Aeronautics and Space Administration's Planetary Geology and Geophysics Program (Fortezzo and others, 2008; Grant and others, 2009; Williams, 2010).

\section{Mapping Methods and Data}

Our photogeologic mapping approach delimited unconformity-bounded geologic units rather than units based only on secondary erosional or structural landforms (Salvatore, 1994; Tanaka and others, 2005). In some cases, significant outcrops such as LTLDs are $<2 \mathrm{~km}$ across ( $2 \mathrm{~mm}$ at map scale), so we grouped them with a more extensive cap rock, although it was uncertain whether the LTLDs and cap rock have the same lateral extent. Unit names are descriptive where unique primary morphology was evident (for example, fan 2 unit, chaotic unit, crater 1 unit, dune unit), but basin-filling materials of more ambiguous origin and composition have unit names based on their geographic and stratigraphic location (for example, the basin fill 1 unit is older than the basin fill 2 unit).

The U.S. Geological Survey provided the $231 \mathrm{~m} /$ pixel base map derived from the Viking Mars Digital Image Mosaic 2.1. The base uses a transverse Mercator projection, the Mars Orbiter Laser Altimeter (MOLA) 2000 datum, and a central meridian of $330^{\circ} \mathrm{E}$. We made an equivalent base mosaic using Mars Odyssey Thermal Emission Imaging System (THEMIS) daytime infrared (DIR) imaging at $100 \mathrm{~m} /$ pixel (fig. 2), and we reprojected and georeferenced part of the Arizona State University THEMIS nighttime infrared mosaic 2.0 at $231 \mathrm{~m} /$ pixel as an overlay (fig. 3). Detailed mapping was based on THEMIS visible images at $18 \mathrm{~m} /$ pixel and Mars Reconnaissance Orbiter (MRO) Context Camera images at $5 \mathrm{~m} /$ pixel. Where available, Mars Orbiter Camera (MOC) images at $\sim 2-5 \mathrm{~m} /$ pixel, MRO High Resolution Imaging Science Experiment (HiRISE) visible images at $25 \mathrm{~cm} / \mathrm{pixel}$, and Compact Reconnaissance Imaging Spectrometer for Mars (CRISM) products facilitated local interpretations of within-unit 
stratigraphy. Topographic measurements were based on the 128 pixel/degree MOLA Mission Experiment Gridded Data Record. Using ArcGIS 9.3, we drafted line work at 1:250,000 scale for publication at 1:1,000,000 scale. Unit contacts have a streamdigitized vertex spacing of $\sim 500 \mathrm{~m}$ and are attributed as definite or approximate. Linear features include faults, crater rims, and small valleys.

\section{Age Determinations}

We constrained age relations using a count of all primary craters $>1 \mathrm{~km}$ in diameter, as seen in THEMIS DIR imaging of the map area (some secondary craters $1-2 \mathrm{~km}$ in diameter may have inadvertently been included, particularly near Holden crater). We did not exclude any surfaces from the counts for each unit. The resulting relative ages (table 1) are consistent with observed superposition and crosscutting relations, within the error bars of the crater counts. Unit ages are reported as $\mathrm{N}(\mathrm{x})$, the number of craters greater than $\mathrm{x} \mathrm{km}$ in diameter per $10^{6} \mathrm{~km}^{2}$, plus or minus the square root of the count, also normalized to $10^{6} \mathrm{~km}^{2}$. The geologic epoch associated with each count and range of epochs covered by the error bars are also given (Werner and Tanaka, 2011). Isochron plots using the Hartmann (2005) method are provided for large surfaces including the entire map area, the terra unit, and the Holden crater rim and ejecta. These plots show model absolute ages for major resurfacing events, listed oldest to youngest:

- $\quad$ Ladon and Holden basin impacts (prior to $~ 3.7-3.9 \mathrm{Ga}$ )

- decline of ubiquitous crater degradation and loss of small craters $(3.5-3.7 \mathrm{Ga})$

- Holden crater impact ( 3.0-3.5 Ga)

These model ages highlight the uncertain timespan over which most of the landscape degradation occurred, but prolonged crater degradation with at least intermittent fluvial erosion appears to have modified the Martian surface over hundreds of millions of years.

\section{Regional Geology}

The map area's diverse geologic units formed during three to four distinct epochs of erosion and resurfacing, which include two relatively brief but important flooding events (Grant, 1987). Geophysical and isotopic evidence suggests that the crust formed within the first 50 m.y. of Martian history. The isostatically compensated long-wavelength topography of the crustal dichotomy dates to the pre-Noachian Period, before the relict cratering record was established (Solomon and others, 2005; Nimmo and Tanaka, 2005; Andrews-Hanna and others, 2008; Irwin and Watters, 2010). Early loading of the lithosphere by Tharsis, located north of the map area, may be responsible for the Chryse trough, which is visible across the map area (Phillips and others, 2001). Basin and ring structures of the
Middle Noachian or older Ladon and superimposed Holden impact basins have survived to the present (Schultz and others, 1982). The inner/outer ring diameters are 500/1,000 km and 300/600 km for Ladon and Holden impact basins, respectively. These structures and their associated topography controlled the planform of later flood channels and smaller fluvial valleys (for example, Parker, 1985; Grant, 1987; Grant and Parker, 2002), which are mostly radial to basin centers or follow the basins' outer rings (fig. 2).

The first time interval of landscape degradation was concurrent with heavy meteorite bombardment (Grant, 1987), such that larger, older craters are more heavily degraded than are smaller, younger ones (Craddock and Maxwell, 1993). The suite of physical processes involved in Noachian degradation tended to smooth the high-frequency relief in the highland landscape, including a reduction in the population of small $(<30 \mathrm{~km}$ diameter) impact craters (for example, Neukum and Hiller, 1981; Strom and others, 1992), rim erosion and infilling of larger craters (for example, Forsberg-Taylor and others, 2004), and retreat of promontories and scarps. In this map area, few Noachian craters $<8 \mathrm{~km}$ in diameter are preserved (figs. 4-6). As seen across much of Mars, the resulting landscape was never integrated into mature drainage basins (for example, Pieri, 1980; Stepinski and Stepinski, 2005; Luo and Howard, 2005), and it is undersaturated with both small craters and small valleys, suggesting that neither impact cratering nor fluvial erosion achieved the dominance found on the Moon and Earth, respectively. Relatively high infiltration capacities that helped to limit runoff may have further inhibited valley incision (Grant, 1999, 2000). Irwin and others (2011) interpreted the Noachian highlands as a transportlimited landscape, where weathering outpaced weak and (or) intermittent fluvial erosion until near the Noachian/Hesperian transition, allowing long-term reduction of relief without substantial incision of valleys. Crater size-frequency distributions suggest that this early epoch of landscape degradation had two definable components (Grant, 1987). Eberswalde crater formed and was partially degraded during this time.

Incision of branching valleys characterized the second time interval of erosion at approximately the Noachian/Hesperian transition. Howard and others (2005) suggested possible causes, including an increase in the magnitude and (or) frequency of precipitation events, a reduction in the weathering rate and sediment supply, or formation of a duricrust that facilitated incision by reducing the infiltration capacity and (or) sediment supply. The declining impact flux and high rates of volcanic activity in the Late Noachian to Early Hesperian epochs (for example, Greeley and Schneid, 1991) may have facilitated atmospheric thickening around that time.

Incision of the Uzboi, Ladon, and Morava Valles mesoscale outflow channels represents a significant erosional event in the Late Noachian to Early Hesperian epochs (table 1). The slope of the crustal dichotomy/Chryse trough controlled the overall flow path, which was locally reoriented radial to the Holden and Ladon impact basins (figs. 1, 2). Uzboi Vallis heads at the incised margin of the Argyre impact basin and delivered enough water to overflow both the Holden and Ladon impact basins (Parker and Pieri, 1985c). The multiple anabranching 
outlet channels of Ladon and Morava Valles reflect rapid flooding of the basins and a high discharge that the pre-valley topography could not confine into a single channel. The only evident source for these large flows is Argyre basin (Parker, $1985,1994)$, which may have collected meltwater from a contemporary southern polar ice cap (Clifford and Parker, 2001). The topographically defined contributing watershed extended far to the south of Argyre and encompassed as much as 9 percent of the surface of Mars (Banerdt, 2000). Flow appears to have continued through the informally named Margaritifer basin to the northern lowlands via Mawrth and, perhaps, Ares Valles (Grant and Parker, 2002; Rotto and Tanaka, 1995; Irwin and Grant, 2009). This is the first and larger of two discrete erosional events driven by water that was exotic to the map area. It also represents a rare but high-volume return flow of surface water from high southern latitudes to the lowlands, independent of slower atmospheric or subsurface pathways. The Martian highlands maintained a multibasin landscape throughout the Noachian period, and few channels were established for surface drainage from enclosed southern basins.

Holden and (the stratigraphically younger) Ostrov craters formed in the Hesperian period, based on crater counts (table 1). Their ejecta morphology is subdued, but their central peaks and secondary craters are still visible, particularly north of the craters' continuous ejecta. Holden crater interrupted distal Uzboi Vallis (fig. 1), where it had debouched into the Holden impact basin (Bond and Hale craters also overlie Uzboi Vallis near its head, outside of the study area; fig. 1). Holden crater ejecta mostly buried the older Eberswalde crater to the north. Following the Holden and Ostrov impacts, LTLDs and coarse-grained alluvial fans accumulated in the craters over an unknown period of time.

A Hesperian flooding event postdates deposition of LTLDs in Holden crater. The Holden crater rim had dammed Uzboi Vallis, forming an enclosed basin within the valley between the rims of Holden and Bond craters. The low point of the basin's divide was the Holden crater rim at $-350 \mathrm{~m}$. A lake formed in Uzboi Vallis from sources on the surrounding cratered surface and (or) from its Nirgal Vallis tributary, accumulating phyllosilicate-bearing LTLDs (fig. 7) like those found in Holden and Eberswalde craters (Grant and others, 2010). A phyllosilicate-bearing layer occurs near the top of the section exposed in Nirgal Vallis southwest of the map area (Buczkowski and others, 2010), and it may provide a concentrated source for these phyllosilicates. This lake overflowed and incised the Holden crater rim, initially forming multiple channels (fig. 8) before flow coalesced into one entrance breach, draining the lake almost entirely and incising an inner valley $30 \mathrm{~km}$ up the Uzboi Vallis floor (Grant and Parker, 2002; Grant and others, 2008). The multiple overflow points again suggest a substantial discharge into and from the 4,000- $\mathrm{km}^{3}$ Uzboi lake, and the inner valley shows that discharge through Uzboi Vallis somewhat outlasted drawdown of the lake. However, flow through the system was not geologically long-lived, because the Uzboi Vallis floor is not fully dissected, and deposits in Holden crater related to the breach were not incised or reworked (fig. 8). If any deposits accumulated in Nirgal Vallis during the infilling of Uzboi Vallis, they were eroded during and after drawdown of the lake. These observations are consistent with a geologically brief episode of infilling and breaching in Uzboi Vallis.

A possible alternative scenario involves initially slow drainage from Uzboi Vallis into Holden crater (over or through the fractured crater rim) for a period of time before the rim breach and flooding occurred. This source of clear water could have maintained a paleolake in Holden crater long enough for LTLDs to accumulate from erosion of the crater walls. Finally, a positive feedback between rim erosion and discharge resulted in catastrophic drainage of the Uzboi lake into Holden crater. A similar delayed outflow occurred at paleolake Bonneville in the western United States, where the basin's outlet (an alluvial fan at Red Rock Pass, Idaho) maintained the lake level at the Bonneville high stand for some time before a catastrophic incision and flood (O'Connor, 1993). In this scenario, the angular unconformity between LTLDs and overlying coarse-grained stratigraphy in Holden crater (all within the layered unit, $\mathrm{HI}$, or between the layered unit and the fan 1 unit, $\mathrm{Hf}_{1}$ ) would represent very little time.

Alluvial fans continued to develop in Holden crater for some time after the Uzboi flood, although perhaps under drier conditions. The southern end of the Holden bajada overlies the termini of flood channels from the Uzboi rim breach. Floor fractures in Holden crater crosscut deposits from Uzboi Vallis, but they do not crosscut alluvial fans that they intersect, also suggesting that fan activity extended beyond the Uzboi flood. Grant and Wilson (2011) dated the end of alluvial fan development to the Amazonian period, perhaps as early as the Hesperian/ Amazonian boundary. It is unclear whether the Eberswalde delta was contemporary with flooding from Uzboi Vallis into Holden crater or with later fan activity, but the alluvial fans in other topographically isolated craters in the region suggest that fan development was a regional occurrence and not dependent on water from Uzboi Vallis. The Eberswalde delta was not deeply entrenched by its contributing stream as the lake level fell, suggesting that fluvial erosion declined abruptly relative to Pleistocene/Holocene climate change on Earth (Irwin and others, 2005). The multibasin highland plateau may have accelerated this decline by topographically and thermally trapping water (Irwin and others, 2011). Subsequent erosion was primarily aeolian and most effective on friable deposits, including LTLDs and interchannel fines on alluvial fans. The preservation of Late Noachian to Hesperian landforms on Mars attests to the severe decline in weathering and erosion rates around that time (Craddock and others, 1997; Golombek and others, 2006).

Late Hesperian to Early Amazonian extensional faults and chaotic terrains are concentrated on basin surfaces as well as in Ladon and Morava Valles. The chaotic terrains are mostly located within and may have been influenced by older multiringed impact basin structures. 


\section{Stratigraphy}

\section{Noachian Period}

The oldest map unit is the Middle Noachian (or perhaps older) mountainous unit ( $\mathrm{Nm})$, composed of isolated bedrock promontories with Noachian or older crystallization ages and exposed as fractured ring structures during the Ladon and Holden basin impacts (Schultz and others, 1982). Noachian landscape degradation reduced these mountains in size and created fringing pediments or deposits of terra unit material. The mountainous unit also includes the central peak structures of Holden and Ostrov craters, which are interpreted to similarly expose deep crustal rocks.

The most widespread unit is the Late Noachian to Early Hesperian terra unit (HNt), which includes a diverse and spatially variable mix of fractured basaltic bedrock (Bandfield and others, 2000), impact ejecta, weathered rocks (Murchie and others, 2009), fluvially reworked sediments, airfall or aeolian traction materials, and perhaps other types of rocks. The unit is interpreted as a geomorphic surface composed of both erosional and depositional outcrops, and it cannot be meaningfully subdivided (Tanaka and others, 2005). Fluvial dissection is common, particularly on slopes, and stratification is evident in some places. Terra unit surfaces are typically rolling and do not retain small craters well, relative to many smooth basin fills (Malin, 1976; Malin and Edgett, 2001). Impact gardening during and after the Noachian period has substantially reworked these surfaces (Hartmann and others, 2001). Noachian landscape-degradation processes reworked the interior slopes of the Middle Noachian or older Ladon and Holden impact basins, so these areas are included in the terra unit. Superimposed craters suggest that substantial crater degradation continued into the Early Hesperian epoch in the map area (table 1).

\section{Hesperian Period}

Late Noachian to Early Hesperian channel materials of Uzboi, Ladon, and Morava Valles include exposed bedrock outcrops, eroded surfaces of the terra unit, and veneers of alluvial sediment. The channel 1 unit $\left(\mathrm{HNch}_{1}\right)$ represents initial dissection of the surface; these surfaces were abandoned when flow coalesced and downcut the main channels $\left(\mathrm{HNch}_{2}\right)$, which conveyed any later flows out of Argyre basin. The eroded morphology and widespread, presumably alluvial, surfaces in the channel 1 unit distinguish it from the terra unit. Based on the $>1-\mathrm{km}$ crater population, the $\mathrm{HNch}_{1}$ and $\mathrm{HNch}_{2}$ units do not have distinguishable ages $(\mathrm{N}(1)=3,959 \pm 534$ and 3,983 \pm 996 , respectively), and Holden and Ostrov secondary craters in the area complicate counts at smaller diameters. However, crude layering in the Ladon impact basin seen in meter-resolution imaging (fig. 9) suggests multiple pulses of discharge into the basin (Grant and Parker, 2002).

In Holden impact basin, Holden crater ejecta partially resurfaced an older fill unit (basin fill 1 unit, $\mathrm{HNb}_{1}$ ), and the sequence subsequently developed a knobby morphology. Later sedimentary deposits and recent aeolian sand have partially infilled this rough surface (fig. 10). The Holden impact basin also contains a superimposed thick fill unit (basin fill 2 unit, $\mathrm{HNb}_{2}$ ) that appears similar to fill materials confined to other impact craters in the area (smooth plains that retain small superimposed craters). It is interpreted as moderately to strongly indurated alluvial, volcanic, or aeolian materials; origin and composition may vary within and between individual basins.

Contemporary units in Ladon basin include the basin fill 2 $\left(\mathrm{HNb}_{2}\right)$ and basin fill $3\left(\mathrm{Hb}_{3}\right)$ units. Higher-standing $\mathrm{HNb}_{2}$ surfaces uplifted by compressional faulting consist of a partly stripped, darker-toned surface layer and underlying mediumto lighter-toned materials (fig. 11), which overlie the crudely stratified deposit mentioned above. The mechanical weakness and rugged texture of the stripped and lighter-toned materials are consistent with moderately indurated sedimentary deposits but not basaltic lava flows. The lighter-toned layer may represent fine-grained aqueous sediments, evaporites, or a duricrust, which are all consistent with a large arid-zone basin. The $\mathrm{Hb}_{3}$ unit embays the $\mathrm{HNb}_{2}$ unit, is darker in tone, preserves a dense population of small impact craters, and has a higher nighttime brightness temperature. The crater counts (table 1) for these two units collectively are similar to those for the Uzboi, Ladon, and Morava flood and to the end of widespread crater degradation in the area. The exposed stratigraphy in Ladon basin suggests multiple facies and depositional environments, which we interpret to consist of coarse flood deposits from Ladon Vallis, finer-grained alluvium from radial valley networks (both part of $\mathrm{HNb}_{2}$ ), and embayment by volcanic materials or perhaps wellindurated sedimentary deposits $\left(\mathrm{Hb}_{3}\right)$.

The Hesperian ejecta of Holden and Ostrov craters $\left(\mathrm{Hc}_{1}\right)$ postdate all of the units above and resurfaced much of the southern third of the map area. These ejecta and secondary craters were then modestly degraded and dissected. The timing of these two impacts is confirmed by their mutually consistent crater counts, superposition of Holden crater on Uzboi Vallis, observation of Holden crater secondaries on the Ladon impact basin floor deposits, and superposition of Ostrov secondaries over those of Holden crater. Megabreccia from the Holden crater impact is exposed along the southern crater wall (Grant and others, 2008). A resistant unit on the Holden and Eberswalde crater floors $(\mathrm{He})$, where overlying sedimentary deposits have mostly been removed (although small stratified outcrops remain), may be composed of materials related to the impact or early infilling deposits.

After the Holden crater impact, Holden and Eberswalde craters accumulated thinly bedded, phyllosilicate-bearing LTLDs (Lewis and Aharonson, 2006; Grant and others, 2008; Milliken and Bish, 2010) (fig. 12), suggesting a similar depositional environment. The largest outcrops of these rocks occur where they are exposed beneath a more resistant capping material; this cap rock defines the mapped extent of the layered unit $(\mathrm{HI})$. In Holden crater, the thickness of beds in at least the upper part of the section is less than a meter (it is difficult to define bed thickness in some portions of the lower and middle LTLD members in Holden crater, fig. 13), and beds are laterally traceable for as much as kilometer distances. The deposits are generally confined to low, common elevations within the craters and 
do not drape high-standing surfaces (except for some breached intercrater basins west of Eberswalde), favoring low-energy alluvial or lacustrine deposits rather than airfall materials or volcanic ash. The deposits are weakly indurated and susceptible to aeolian erosion, consistent with a fine grain size. Alluvial fans and paleochannels overlie the LTLDs in both craters, consistent with aqueous deposition.

The origin of phyllosilicates observed in LTLD outcrops (part of units $\mathrm{He}$ and $\mathrm{HI}$ ) of Holden crater, Eberswalde crater, Ladon impact basin, Uzboi Vallis, and other depressions has important implications for habitability (Grant and others, 2008; Milliken and Bish, 2010). To account for landscape degradation, the highland surface must have undergone prolonged chemical and mechanical weathering during heavy impact bombardment. Flowing water may have reworked phyllosilicates from weathered upland surfaces and transported them into depositional basins, although some phyllosilicates were likely produced by weathering of the basin walls. Holden crater drained internally for most of its erosion, so phyllosilicates were either eroded from sedimentary rocks exposed on the crater walls, or substantial chemical weathering occurred within the crater (Grant and others, 2008; Milliken and Bish, 2010), possibly due in part to impact-related hydrothermal alteration (Newsom and others, 1996; Schwenzer and Kring, 2009).

Other stratified deposits in Holden crater are the fan 1 unit $\left(\mathrm{Hf}_{1}\right)$ and the Holden central unit $(\mathrm{Hh})$. The fan 1 unit is coarse grained with many boulders visible in HiRISE imaging, despite the fan's low gradient. Its coarse bedding has steeper dips and truncations near the mouth of Uzboi Vallis, grading to more planar bedding toward the center of the crater (Grant and others, 2008). The fan has a multi-lobed planform emanating from Uzboi Vallis into the crater. These characteristics suggest origin during a large flood when a paleolake in Uzboi Vallis breached the Holden crater rim (Grant and Parker, 2002). One lobe was oriented toward a gap in Holden crater's inner ring, which confines much of the Holden central unit (Hh). Unit Hh is defined by its low albedo, low thermal inertia, and overall smooth morphology with some rugged outcrops of underlying material. The Holden central unit is interpreted as fine-grained, low-energy deposits that have been substantially etched and mostly buried by a recent aeolian sand sheet (Pondrelli and others, 2005).

Holden and Ostrov craters include some of the most extensive, best-preserved alluvial fans on Mars $\left(\mathrm{AHf}_{2}\right)$. Large alluvial fans formed preferentially along the rims of deep, Late Noachian to Hesperian impact craters that were not substantially modified by the earlier crater degradation (Moore and Howard, 2005). Ostrov crater has unusually deep rim dissection around the entire crater wall, sourcing an alluvial bajada that spans the circumference of the crater (fig. 14). These fans ramp down to the central peak, which is fringed by a small area of low-relief stratified deposits. The lack of evidence for deep ponding suggests that the groundwater table in the area was typically low or below the crater floor, consistent with infrequent runoff in an arid Hesperian paleoclimate.

Holden crater contains a fringing bajada along its west wall, but the east wall experienced very little erosion or deposition. Having formed on the inner ring of the older Holden impact basin, Holden crater's west rim stands higher than its east rim. It is possible that an orographic effect enhanced precipitation from easterly winds, although orographic enhancement by the crater itself was not required at Ostrov, and other craters with fans show no consistent relation between the fan orientation and regional air flow (Kraal and others, 2008). Alternatively, the greater rim dissection may be due to the larger relief and surface area of the slope, enhancing the erosive power of runoff to above some threshold for incision or gravel transport. The bajada has a relation between contributing area and slope that is consistent with fluvial rather than debris-flowdominated fans on Earth, and the inverted channels common on fan surfaces show that interchannel deposits were dominantly composed of sand and fines (Moore and Howard, 2005), so high-magnitude runoff by terrestrial standards may have been uncommon or absent at these sites. The inverted paleochannels reflect aeolian deflation, or delicate distributary patterns would not be preserved, so a supply of fines was required either from the source alcoves or less likely from in-situ weathering.

The putative delta at Eberswalde crater has several features in common with alluvial deposits elsewhere in the map area. The Eberswalde delta was sourced from a drainage basin to the west, which had been resurfaced by Holden crater ejecta (Malin and Edgett, 2003; Moore and others, 2003; Pondrelli and others, 2008). The alluvium (fig. 15) likely consists of Holden crater ejecta, weathered rocks from the subjacent terra unit, and materials from the dissected Eberswalde rim, which are similar source rocks to alluvium occurring in Holden crater fans. Relief inversion of distributary paleochannels occurred in both areas but is more pronounced at Eberswalde, possibly reflecting a greater thickness or finer caliber of interchannel fines in its lower-energy depositional environment. Finally, both craters record somewhat variable water levels. In northwestern Holden crater, some stratigraphically older alluvial fans have distal scarps, suggesting either base-level control on deposition or erosion of the fan toe at a lower lake level. The strongest evidence for deep lakes in Holden crater is the occurrence of LTLDs at least $150 \mathrm{~m}$ thick and at elevations up to about $-2,000 \mathrm{~m}$ along the crater walls, $300 \mathrm{~m}$ above the floor. In Eberswalde, lateral migration of river channels suggests base-level stability over century timescales, although multiple lobes of the delta indicate somewhat variable lake levels over much longer periods (Bhattacharya and others, 2005; Pondrelli and others, 2008). The fan stratigraphy suggests an aggrading delta surface (Lewis and Aharonson, 2006).

The development of alluvial fans at Holden and a delta at Eberswalde likely reflects differences in the topography of the contributing area, rather than any significant difference in the paleoclimate or hydrology between the two adjacent sites. Eberswalde crater had an $\sim 5,000 \mathrm{~km}^{2}$ contributing watershed (not including the crater), but it was a smaller basin, helping to maintain deep-standing water. The paleolake had an area of $\sim 400 \mathrm{~km}^{2}$ at approximately the $-1,400 \mathrm{~m}$ contour, so runoff production from the contributing watershed was roughly $1 / 12$ the evaporation rate of the lake. Neither Eberswalde nor Holden craters overflowed. Holden crater's internal contributing area was $\sim 19,000 \mathrm{~km}^{2}$, and the lake area would be $\sim 9,800 \mathrm{~km}^{2}$ at 
the $-2,000 \mathrm{~m}$ contour. Maintaining a sizeable lake in Holden crater before the rim was breached would have required either a greater precipitation rate than that at Eberswalde, which seems unlikely, or substantial contributions from Uzboi Vallis or regional groundwater (Holden crater is the deepest large basin within $700 \mathrm{~km}$ ). The Holden impact basin's inner ring and the Holden crater rim defined Eberswalde crater's external watershed, which had a lower gradient than Holden's steep walls and may have delivered finer sediment to the west side of Eberswalde.

Mass movements in the map area are restricted to the entrance breach where Uzboi Vallis enters Holden crater, but this outcrop is too small to show at map scale. Incision of the breach appears to have triggered slides that may have punctuated the water and sediment flux into the crater. The final slide postdates erosion of the breach and is not modified by fluvial erosion.

\section{Amazonian Period}

Development of large alluvial fans appears to have continued into the Amazonian Period (Grant and Wilson, 2011). The only other sizeable Amazonian unit in the map area is the dune field (Ad) just inside the central ring of Holden crater. This deposit formed by transport of sand from the north. Its abundance of barchan dunes reflects a limited sand supply. At higher resolution, dark-toned aeolian ripples and sand sheets are common in the map area, particularly in topographic lows or corridors between elevated outcrops.

\section{Structural Features}

Most of the visible faults in the area date to the Late Hesperian or Early Amazonian epochs. These include compressional wrinkle ridges, mostly in the terra unit $(\mathrm{HNt})$, and Late Hesperian to Early Amazonian extensional faults or floor fractures that are concentrated in and around the Ladon impact basin floor. The wrinkle ridges are mostly circumferential to Tharsis, and some older graben structures (ones that predate the final pulse of fluvial activity in the Hesperian) are radial to it (Grant, 1987).

Chaotic terrains are discrete areas of severe structural disruption that are often but not always confined to basins. They are commonly interpreted as collapse features, and the source of the subsurface void space is not well understood. Sharp (1973) commented that processes involving ground ice were volumetrically inadequate to the scale of the features and found magmatic flows more satisfactory. Chapman and Tanaka (2002) envisioned an interaction between magma and ground ice in forming chaotic terrains. In the map area, we find that many chaotic knobs in Morava Valles are topographically positive relative to the channel floor that they disrupt. Similarly, floor-fractured areas in southeastern Holden crater and Ladon Vallis are uplifted relative to older channel floors and alluvial deposits. Volcanic intrusions may be the most viable means of generating the localized uplift and creating the void space in the subsurface needed for subsequent collapse. Impact basin structures may have facilitated both floor fracturing and chaotic terrain development by these intrusions (Schultz, 1976).

\section{Conclusions}

The geology of the map area is summarized as follows (table 1, figs. 4-6):

\section{Pre-Noachian Period}

1. The long-wavelength topography of the crustal dichotomy formed.

\section{Noachian Period}

1. Middle Noachian or older impacts of the informally named Ladon and superimposed Holden impact basins exposed mountainous unit rocks $(\mathrm{Nm})$.

2. The visible cratering record dates back to approximately the Middle/Late Noachian transition, based on $\mathrm{N}(16)$ populations of fresh and degraded craters.

3. Slow landscape degradation continued throughout the Noachian period, forming the terra unit $(\mathrm{HNt})$. Relief reduction and smoothing occurred as weathering outpaced fluvial and aeolian transport of the weathered debris.

4. Starting approximately at (potentially before) the Noachian/Hesperian transition, overflow of Argyre basin sent a catastrophic flood down the Chryse trough, overflowing and breaching Holden and Ladon basins and incising Uzboi, Ladon, and Morava Valles, and possibly Mawrth and (or) part of Ares Valles to the north. Early flooded surfaces represent the channel 1 unit $\left(\mathrm{HNch}_{1}\right)$, whereas later flow coalesced into a single channel, the channel 2 unit $\left(\mathrm{HNch}_{2}\right)$.

\section{Hesperian Period}

1. Degraded craters and the Holden impact basin (units $\mathrm{HNb}_{1}$ and $\mathrm{HNb}_{2}$ ) accumulated fill materials during the Noachian period and into the Early Hesperian epoch. The Ladon basin floor $\left(\mathrm{HNb}_{2}, \mathrm{Hb}_{3}\right)$ accumulated older sediments from the Uzboi, Ladon, and Morava system, later fluvial deposits from centripetally draining valleys, and possibly volcanic flows, all ending around the time that crater degradation declined in the Early Hesperian epoch.

2. The Hesperian impacts of Holden and Ostrov craters $\left(\mathrm{Hc}_{1}\right)$ resurfaced the southwestern part of the map area.

3. Light-toned, layered deposits accumulated in Eberswalde and Holden craters, as well as Uzboi and Ladon Valles (unit $\mathrm{HI}$ ). Development of alluvial fans $\left(\mathrm{AHf}_{2}\right)$ may have begun around this time. 
4. Overflow of the Holden crater rim by a lake in Uzboi Vallis deposited bouldery flood deposits $\left(\mathrm{Hf}_{1}\right)$ in Holden crater. Deposition of fine-grained stratified deposits inside the Holden crater inner ring $(\mathrm{Hh})$ may have been contemporary.

\section{Amazonian Period}

1. Late Hesperian to Early Amazonian chaotic terrain development (AHct) reflects uplift and dense fracturing followed by partial collapse, likely due to volcanic intrusion.

2. Alluvial fan development $\left(\mathrm{AHf}_{2}\right)$ may have continued into the Amazonian period.

3. Stripping of the layered unit $(\mathrm{HI})$ from parts of the Eberswalde and Holden crater floors exposed older, potentially impact-related materials at the base of the etched unit $(\mathrm{He})$.

4. Fresh impact craters $\left(\mathrm{AHc}_{2}\right)$ that superimpose Noachian units date to the Hesperian and Amazonian periods.

5. The dune field (Ad) in Holden crater formed by sand transport from the north side of the crater, and smaller aeolian sand sheets formed in many locations.

6. Aeolian degradation of friable sedimentary deposits continued, leaving uncratered surfaces on some Hesperian geologic units.

\section{References Cited}

Andrews-Hanna, J.C., Zuber, M.T., and Banerdt, W.B., 2008, The Borealis basin and the origin of the martian crustal dichotomy: Nature, v. 453, p. 1212-1216, doi:10.1038/ nature 07011.

Baker, V.R., 1982, The channels of Mars: Austin, Tex., University of Texas Press, 198 p.

Bandfield, J.L., Hamilton, V.E., and Christensen, P.R., 2000, A global view of Martian surface compositions from MGS-TES: Science, v. 287, p. 1626-1630, doi: 10.1126/ science.287.5458.1626.

Banerdt, W.B., 2000, Surface drainage patterns on Mars from MOLA topography: Eos, Transactions of the American Geophysical Union, fall meeting supplement, v. 81, no. 48, Abstract \#P52C-04.

Bhattacharya, J.P., Payenberg, T.H.D., Lang, S.D., and Bourke, M.C., 2005, Dynamic river channels suggest a long-lived Noachian crater lake: Geophysical Research Letters, v. 32, no. L10201, doi:10.1029/2005GL022747.

Boothroyd, J.C., 1982, Ancient fluvial drainage systemsMargaritifer Sinus area, Mars, in Reports of planetary geology program - 1982: Washington, D.C., National Aeronautics and Space Administration Technical Memorandum 85127, p. 209-212.

Buczkowski, D.L., Seelos, K., Murchie, S., and 4 others,
2010, Extensive phyllosilicate-bearing layer exposed by valley systems in northwest Noachis Terra, in Lunar and Planetary Science Conference, XLI: Houston, Tex., Lunar and Planetary Institute, Abstract \#1458.

Carr, M.H., 1996, Water on Mars: New York, N.Y., Oxford University Press, $229 \mathrm{p}$.

Chapman, M.G., and Tanaka, K.L., 2002, Related magma-ice interactions - Possible origins of chasmata, chaos, and surface materials in Xanthe, Margaritifer, and Meridiani Terrae, Mars: Icarus, v. 155, p. 324-339.

Clifford, S.M., and Parker, T.J., 2001, The evolution of the Martian hydrosphere-Implications for the fate of a primordial ocean and the current state of the northern plains: Icarus, v. 154, p. 40-79.

Craddock, R.A., and Maxwell, T.A., 1993, Geomorphic evolution of the Martian highlands through ancient fluvial processes: Journal of Geophysical Research, v. 98, p. 3453-3468.

Craddock, R.A., Maxwell, T.A., and Howard, A.D., 1997, Crater morphometry and modification in the Sinus Sabaeus and Margaritifer Sinus regions of Mars: Journal of Geophysical Research, v. 102, p. 13,321-13,340.

Florenski, C.P., Basilevsky, A.T., Kuzmin, R.O., and Chernaya, I.M., 1975, Geomorphologic analysis of some Martian surface images from the Mars 4 and 5 automatic stations: Icarus, v. 26, p. 219-229.

Forsberg-Taylor, N.K., Howard, A.D., and Craddock, R.A., 2004, Crater degradation in the Martian highlandsMorphometric analysis of the Sinus Sabaeus region and simulation modeling suggest fluvial processes: Journal of Geophysical Research, v. 109, no. E05002, doi:10.1029/2004JE002242.

Fortezzo, C.M., Williams, K.K., and Grant, J.A., 2008, Geologic history within southeastern Margaritifer Terra, Mars, in Lunar and Planetary Science Conference, XXXIX: Houston, Tex., Lunar and Planetary Institute, Abstract \#2244.

Golombek, M.P., Grant, J.A., Crumpler, L.S., and 8 others, 2006, Erosion rates at the Mars Exploration Rover landing sites and long-term climate change on Mars: Journal of Geophysical Research, v. 111, no. E12S10, doi:10.1029/2006JE002754.

Grant, J.A., 1987, The geomorphic evolution of eastern Margaritifer Sinus, Mars, in Advances in planetary geology: Washington, D.C., National Aeronautics and Space Administration Technical Memorandum 89871, p. 1-268.

Grant, J.A., 1999, Evaluating the evolution of process specific degradation signatures around impact craters: International Journal of Impact Engineering, v. 23, p. 331-340.

Grant, J.A., 2000, Valley formation in Margaritifer Sinus, Mars, by precipitation-recharged ground-water sapping: Geology, v. 28 , p. $223-226$.

Grant, J.A., Buczkowski, D., Irwin, R.P., III, and Siebach, K., 2010, A lake in Uzboi Vallis and implications for Late Noachian climate on Mars, in Lunar and Planetary Science Conference, XLI: Houston, Tex., Lunar and Planetary Institute, Abstract \#1834. 
Grant, J.A., Irwin, R.P., III, Grotzinger, J.P., and 7 others, 2008, HiRISE imaging of impact megabreccia and sub-meter aqueous strata in Holden crater, Mars: Geology, v. 36, p. 195-198.

Grant, J.A., and Parker, T.J., 2002, Drainage evolution in the Margaritifer Sinus region, Mars: Journal of Geophysical Research, v. 107, no. E9, doc. no. 5066, doi:10.1029/2001JE001678.

Grant, J.A., and Wilson, S.A., 2011, Late alluvial fan formation in southern Margaritifer Terra, Mars: Geophysical Research Letters, v. 38, doc. no. L08201, doi:10.1029/2011GL046844.

Grant, J.A., Wilson, S.A., Fortezzo, C.M., and Clark, D.A., 2009, Geologic map of MTM -20012 and -25012 quadrangles, Margaritifer Terra region of Mars: U.S. Geological Survey Scientific Investigations Map 3041, scale 1:500,000.

Greeley, R., and Schneid, B.D., 1991, Magma generation on Mars-Amounts, rates, and comparisons with Earth, Moon, and Venus: Science, v. 254, p. 996-998.

Hartmann, W.K., 2005, Martian cratering 8-Isochron refinement and the chronology of Mars: Icarus, v. 174, p. 294-320, doi:10.1016/j.icarus.2004.11.023.

Hartmann, W.K., Anguita, J., de la Casa, M.A., Berman, D.C., and Ryan, E.V., 2001, Martian cratering 7-The role of impact gardening: Icarus, v. 149, p. 37-53.

Howard, A.D., Moore, J.M., and Irwin, R.P., III, 2005, An intense terminal epoch of widespread fluvial activity on early Mars - 1. Valley network incision and associated deposits: Journal of Geophysical Research, v. 110, no. E12S14, doi:10.1029/2005JE002459.

Irwin, R.P., III, Craddock, R.A., Howard, A.D., and Flemming, H.L., 2011, Topographic influences on development of Martian valley networks: Journal of Geophysical Research, v. 116, doi:10.1029/2010JE003620.

Irwin, R.P., III, and Grant, J.A., 2009, Large basin overflow floods on Mars, in Burr, D.M., Baker, V.R., and Carling, P.A., eds., Megaflooding on Earth and Mars: Cambridge, U.K., Cambridge University Press, p. 209-224.

Irwin, R.P., III, Howard, A.D., Craddock, R.A., and Moore, J.M., 2005, An intense terminal epoch of widespread fluvial activity on early Mars - 2. Increased runoff and paleolake development: Journal of Geophysical Research, v. 110, no. E12S15, doi:10.1029/2005JE002460.

Irwin, R.P., III, and Watters, T.R., 2010, Geology of the Martian crustal dichotomy boundary-Age, modifications, and implications for modeling efforts: Journal of Geophysical Research, v. 115, no. E11006, doi:10.1029/2010JE003658.

Jerolmack, D.J., Mohrig, D., Zuber, M.T., and Byrne, S., 2004, A minimum time for the formation of Holden Northeast fan, Mars: Geophysical Research Letters, v. 31, no. L21701, doi:10.1029/2004GL021326.

Kraal, E.R., Asphaug, E., Moore, J.M., Howard, A., and Bredt, A., 2008, Catalogue of large alluvial fans in martian impact craters: Icarus, v. 194, p. 101-110.

Lewis, K.W., and Aharonson, O., 2006, Stratigraphic analysis of the distributary fan in Eberswalde crater using stereo imagery: Journal of Geophysical Research, v. 111, no. E06001, doi:10.1029/2005JE002558.

Luo, W., and Howard, A.D., 2005, Analysis of Martian valley network basins using a circularity function: Journal of Geophysical Research, v. 110, no. E12S13, doi:10.1029/2005JE002506.

Malin, M.C., 1976, Nature and origin of intercrater plains on Mars, in Studies of the surface morphology of Mars: Pasadena, California Institute of Technology, unpublished Ph.D. dissertation.

Malin, M.C., and Edgett, K.S., 2000, Sedimentary rocks of early Mars: Science, v. 290, p. 1927-1937.

Malin, M.C., and Edgett, K.S., 2001, Mars Global Surveyor Mars Orbiter Camera-Interplanetary cruise through primary mission: Journal of Geophysical Research, v. 106, p. 23,429-23,570.

Malin, M.C., and Edgett, K.S., 2003, Evidence for persistent flow and aqueous sedimentation on early Mars: Science, v. 302, p. 1931-1934, doi:10.1126/science.1090544.

Milliken, R.E., and Bish, D.L., 2010, Sources and sinks of clay minerals on Mars: Philosophical Magazine, v. 2010, p. 1-16, doi:10.1080/14786430903575132.

Moore, J.M., and Howard, A.D., 2005, Large alluvial fans on Mars: Journal of Geophysical Research, v. 110, no. E04005, doi:10.1029/2005JE002352.

Moore, J.M., Howard, A.D., Dietrich, W.E., and Schenk, P.M., 2003, Martian layered fluvial deposits-Implications for Noachian climate scenarios: Geophysical Research Letters, v. 30, no. 24, doc. no:2292, doi:10.1029/2003GL019002.

Murchie, S.L., Mustard, J.F., Ehlmann, B.L., and 14 others, 2009, A synthesis of Martian aqueous mineralogy after 1 Mars year of observations from the Mars Reconnaissance Orbiter: Journal of Geophysical Research, v. 114, no. E00D06, doi:10.1029/2009JE003342.

Neukum, G., and Hiller, K., 1981, Martian ages: Journal of Geophysical Research, v. 86, p. 3097-3121.

Newsom, H.E., Brittelle, G.E., Hibbitts, C.A., Crossey, L.J., and Kudo, A.M., 1996, Impact crater lakes on Mars: Journal of Geophysical Research, v. 101, no. E6, p. 14,951-14,956.

Nimmo, F., and Tanaka, K.L., 2005, Early crustal evolution of Mars: Annual Review of Earth and Planetary Sciences, v. 33, p. 133-161.

O’Connor, J. E., 1993, Hydrology, hydraulics, and geomorphology of the Bonneville Flood: Geological Society of America Special Paper 274, 83 p.

Parker, T.J., 1985, Geomorphology and geology of the southwestern Margaritifer Sinus-Northern Argyre region of Mars: Los Angeles, California State University, M.S. thesis.

Parker, T.J., 1994, Martian paleolakes and oceans: Los Angeles, University of Southern California, Ph.D. thesis.

Parker, T.J., and Pieri, D.C., 1985a, Geomorphology and geology of the southwestern Margaritifer Sinus and Argyre regions of Mars-I. Geological and geomorphological overview, in Reports of planetary geology and geophysics program-1984: Washington, D.C., National Aeronautics and Space Administration Technical Memorandum 87563, p. 361-363. 
Parker, T.J., and Pieri, D.C., 1985b, Geomorphology and geology of the southwestern Margaritifer Sinus and Argyre regions of Mars - II. Crater size-frequency distribution curves and geomorphic unit ages, in Reports of planetary geology and geophysics program - 1984: Washington, D.C., National Aeronautics and Space Administration Technical Memorandum 87563, p. 364-366.

Parker, T.J., and Pieri, D.C., 1985c, Geomorphology and geology of the southwestern Margaritifer Sinus and Argyre regions of Mars-III. Valley types and distribution, in Reports of planetary geology and geophysics program-1984: Washington, D.C., National Aeronautics and Space Administration Technical Memorandum 87563, p. 367-368.

Phillips, R.J., Zuber, M.T., Solomon, S.C., and 7 others, 2001, Ancient geodynamics and global-scale hydrology on Mars: Science, v. 291, p. 2587-2591.

Pieri, D.C., 1980, Geomorphology of Martian valleys, in Advances in planetary geology: Washington, D.C., National Aeronautics and Space Administration Technical Memorandum 81979, p. 1-160.

Pondrelli, M., Baliva, A., Di Lorenzo, S., Marinangeli, L., and Rossi, A.P., 2005, Complex evolution of paleolacustrine systems on Mars-An example from the Holden crater: Journal of Geophysical Research, v. 110, no. E04016, doi:10.1029/2004JE002335.

Pondrelli, M., Rossi, A.P., Marinangeli, L., and 4 others, 2008, Evolution and depositional environments of the Eberswalde fan delta, Mars: Icarus, v. 197, p. 429-451, doi:10.1016/j.icarus.2008.05.018.

Rice, M.S., Bell, J.F., III, Gupta, S., and 3 others, 2013, A detailed geologic characterization of Eberswald crater, Mars: Mars, v. 8, p. 15-59, doi:10.1555/mars.2013.0002.

Rice, M.S., Gupta, S., Bell, J.F., III, and Warner, N.H., 2011, Influence of fault-controlled topography on fluviodeltaic sedimentary systems in Eberswalde crater, Mars: Geophysical Research Letters, v. 38, L16203, doi:10.1029/2011GL048149.

Rotto, S., and Tanaka, K.L., 1995, Geologic/geomorphic map of the Chryse Planitia region of Mars: U.S. Geological Survey Miscellaneous Investigations Series Map I-2441, scale 1:5,000,000.

Salvatore, Amos, ed., 1994, International stratigraphic guide - A guide to stratigraphic classification, terminology, and procedure (2nd ed.): Boulder, Colo., The Geological Society of America, Inc., 214 p.

Saunders, S.R., 1979, Geologic map of the Margaritifer Sinus quadrangle of Mars: U.S. Geological Survey Miscellaneous Investigations Series Map I-1144, scale 1:5,000,000.

Schultz, P.H., 1976, Floor-fractured impact craters: Moon, v. 15, p. 241-273.

Schultz, P.H., and Glicken, H., 1979, Impact crater and basin control of igneous processes on Mars: Journal of Geophysical Research, v. 84, p. 8033-8047.

Schultz, P.H., Schultz, R.A., and Rogers, J., 1982, The structure and evolution of ancient impact basins on Mars: Journal of Geophysical Research, v. 87, p. 9803-9820.
Schwenzer, S.P., and Kring, D.A., 2009, Impact-generated hydrothermal systems capable of forming phyllosilicates on Noachian Mars: Geology, v. 37, no. 12, p. 1091-1094, doi:10.1130/G30340A.1.

Scott, D.H., and Tanaka, K.L., 1986, Geologic map of the western equatorial region of Mars: U.S. Geological Survey Miscellaneous Investigations Series Map I-1802-A, scale 1:15,000,000.

Sharp, R.P., 1973, Mars-Fretted and chaotic terrains: Journal of Geophysical Research, v. 78, p. 4073-4083.

Solomon, S.C., Aharonson, O., Aurnou, J.M., and 14 others, 2005, New perspectives on ancient Mars: Science, v. 307, p. 1214-1220.

Stepinski, T.F., and Stepinski, A.P., 2005, Morphology of drainage basins as an indicator of climate on early Mars: Journal of Geophysical Research, v. 110, no. E12S12, doi:10.1029/2005JE002448.

Strom, R.G., Croft, S.K., and Barlow, N.D., 1992, The Martian impact cratering record, in Kieffer, H.H., Jakosky, B.M., Snyder, C.W., and Matthews, M.S., eds., Mars: Tucson, University of Arizona Press, p. 383-423.

Tanaka, K.L., 1986, The stratigraphy of Mars, in Proceedings of the Lunar and Planetary Science Conference, XVII, Part 1, November, 1986: Journal of Geophysical Research, v. 91, supplement, no. B13, p. E139-158.

Tanaka, K.L., Skinner, J.A., Jr., and Hare, T.M, 2005, Geologic map of the northern plains of Mars: U.S. Geological Survey Scientific Investigations Map 2888, scale 1:15,000,000.

Werner, S.C., and Tanaka, K.L., 2011, Redefinition of the crater-density and absolute-age boundaries for the chronostratigraphic system of Mars: Icarus, v. 215, no. 2, p. 603-607.

Williams, K.K., 2010, Geomorphic mapping of MTMs -20022 and -20017-South of Jones crater, Mars, in Lunar and Planetary Science Conference, XLI: Houston, Tex., Lunar and Planetary Institute, Abstract \#2645.

Wood, L.J., 2006, Quantitative geomorphology of the Mars Eberswalde delta: Geological Society of America Bulletin, v. 118, p. 557-566. 
Table 1. Crater counts for spatially extensive map units. Areas are for entire outcrop extents within the map region.

$\left[\mathrm{N}(\mathrm{x})\right.$, number of craters greater than $\mathrm{x} \mathrm{km}$ in diameter per $10^{6} \mathrm{~km}^{2}, \pm$ square root of count, also normalized to $10^{6} \mathrm{~km}^{2}$. Age: EA, Early Amazonian; EH, Early Hesperian; LH, Late Hesperian; LN, Late Noachian; MA, Middle Amazonian; MN, Middle Noachian. Epoch boundaries follow Werner and Tanaka (2011), based on Hartmann (2005) isochrons, for N(1), N(2), N(5), and N(16). Where error bars cross epoch boundaries, the age is followed by the possible range in parentheses, for example EH (EH-LH). ULM, Uzboi-Ladon-Morava outflow system]

\begin{tabular}{|c|c|c|c|c|c|}
\hline$N(x)$ & Area $\left(\mathrm{km}^{2}\right)$ & Count & Per $10^{6} \mathbf{k m}^{2}$ & \pm Error & Age \\
\hline \multicolumn{6}{|c|}{ Map area, all fresh and degraded craters (fig. 4) } \\
\hline $\mathrm{N}(2)$ & 362,008 & 407 & 1,124 & 56 & $\mathrm{LN}$ \\
\hline $\mathrm{N}(5)$ & & 151 & 417 & 34 & $\mathrm{LN}$ \\
\hline $\mathrm{N}(16)$ & & 40 & 110 & 17 & $\mathrm{MN}(\mathrm{MN}-\mathrm{LN})$ \\
\hline
\end{tabular}

Interpretation: Ladon and Holden impact basins, which predate all other map features, formed around the MN/LN transition or earlier.

\begin{tabular}{cccccc}
\hline \multicolumn{5}{c}{ Incision of ULM system, HNch $_{1}$ and $\mathrm{HNch}_{2}$, superimposed fresh and degraded craters } \\
\hline $\mathrm{N}(1)$ & 17,909 & 71 & 3,964 & 470 & $\mathrm{EH}$ \\
$\mathrm{N}(2)$ & 18 & 1,005 & 237 & $\mathrm{LN}(\mathrm{LN}-\mathrm{EH})$ \\
$\mathrm{N}(5)$ & 5 & 279 & 125 & $\mathrm{LN}(\mathrm{LN}-\mathrm{EH})$
\end{tabular}

Interpretation: The ULM system formed in the LN to EH. Uncertainty is higher due to possible inclusion of some Holden secondary craters in the count or exclusion of primaries from it.

\begin{tabular}{|c|c|c|c|c|c|}
\hline \multicolumn{6}{|c|}{ Terra unit $\mathrm{HNt}$ and superimposed $\mathrm{AHc}_{2}$ (fresh craters, fig. 5) } \\
\hline $\mathrm{N}(1)$ & 177,820 & 647 & 3,635 & 143 & $\mathrm{EH}$ \\
\hline $\mathrm{N}(2)$ & & 160 & 899 & 71 & $\mathrm{EH}$ \\
\hline $\mathrm{N}(5)$ & & 32 & 180 & 32 & $\mathrm{EH}(\mathrm{LN}-\mathrm{EH})$ \\
\hline \multicolumn{6}{|c|}{ Interpretation: Crater degradation waned in the $\mathrm{EH}$. } \\
\hline \multicolumn{6}{|c|}{ Ladon impact basin floor $\mathrm{HNb}_{2}$ and $\mathrm{Hb}_{3}$ only (no large fresh craters or their ejecta) } \\
\hline $\mathrm{N}(1)$ & 26,118 & 89 & 3,408 & 361 & $\mathrm{EH}(\mathrm{EH}-\mathrm{LH})$ \\
\hline$N(2)$ & & 31 & 1,187 & 213 & $\mathrm{LN}(\mathrm{LN}-\mathrm{EH})$ \\
\hline \multicolumn{6}{|l|}{$\mathrm{N}(5)$} \\
\hline \multicolumn{6}{|c|}{$\begin{array}{l}\text { Interpretation: The Ladon impact basin floor was resurfaced at about the same time as the ULM flood and the waning of } \\
\text { crater degradation. }\end{array}$} \\
\hline \multicolumn{6}{|c|}{ Ladon impact basin floor $\mathrm{HNb}_{2}, \mathrm{Hb}_{3}$, and superimposed $\mathrm{AHc}_{2}$} \\
\hline $\mathrm{N}(1)$ & 46,171 & 133 & 2,881 & 250 & LH (EH-LH) \\
\hline $\mathrm{N}(2)$ & & 44 & 953 & 144 & $\mathrm{EH}(\mathrm{LN}-\mathrm{EH})$ \\
\hline $\mathrm{N}(5)$ & & 7 & 152 & 57 & $\mathrm{EH}(\mathrm{LN}-\mathrm{LH})$ \\
\hline
\end{tabular}

Interpretation: Large fresh craters resurfaced much of the Ladon basin floor, so ages determined for the entire basin floor are somewhat lower. Probable Holden crater secondaries formed on both basin fill units in Ladon basin.

\begin{tabular}{cccccc}
\hline \multicolumn{5}{c}{ Holden crater Hc${ }_{1}$ and superimposed $\mathrm{AHc}_{2}$ (fig. 6) } \\
\hline $\mathrm{N}(1)$ & 95 & 1,997 & 205 & EA (LH-EA) \\
$\mathrm{N}(2)$ & 47,563 & 31 & 652 & 117 & EH (EH-LH) \\
$\mathrm{N}(5)$ & 5 & 105 & 47 & LH (EH-EA)
\end{tabular}

Interpretation: Holden crater formed in the Hesperian Period.

\begin{tabular}{cccccc}
\hline \multicolumn{5}{c}{ Ostrov crater Hc H $_{1}$ and superimposed $\mathrm{AHc}_{2}$} \\
\hline $\mathrm{N}(1)$ & 50 & 2,471 & 327 & $\mathrm{LH}$ \\
$\mathrm{N}(2)$ & 13 & 642 & 173 & $\mathrm{EH}(\mathrm{EH}-\mathrm{LH})$ \\
$\mathrm{N}(5)$ & 4 & 198 & 99 & $\mathrm{EH}(\mathrm{LN}-\mathrm{LH})$
\end{tabular}

Interpretation: Ostrov crater formed in the Hesperian Period. Superposition of Ostrov secondaries over Holden secondaries suggests that Ostrov is younger. Crater wall erosion and deposition of alluvial fans in Holden and Ostrov craters occurred in the Hesperian or later. Less significant degradation of other Hesperian craters in the map area occurred around this time. 
Table 1. Continued

\begin{tabular}{|c|c|c|c|c|c|}
\hline$N(x)$ & Area $\left(\mathrm{km}^{2}\right)$ & Count & Per $10^{6}$ km² $^{2}$ & \pm Error & Age \\
\hline \multicolumn{6}{|c|}{ Chaotic terrain AHct at Morava Vallis } \\
\hline $\mathrm{N}(1)$ & 5,220 & 9 & 1,719 & 573 & EA (LH-EA) \\
\hline $\mathrm{N}(2)$ & & 2 & 382 & 270 & EA (EH-MA) \\
\hline $\mathrm{N}(5)$ & & 1 & 191 & 191 & \\
\hline \multicolumn{6}{|c|}{$\begin{array}{l}\text { Interpretation: Chaotic terrain formed near Morava Vallis in the LH to EA. Floor fractures crosscut EH to LH materials } \\
\text { in Ladon impact basin, Ladon Vallis, and Holden crater, so the fractures may be contemporary with chaotic terrain develop- } \\
\text { ment. }\end{array}$} \\
\hline
\end{tabular}

